\title{
High-energy ionizing radiation-induced degradation of amodiaquine in dilute aqueous solution: radical reactions and kinetics
}

Krisztina Kovács, Ádám Simon, György Tibor Balogh, Tünde Tóth \& László Wojnárovits

To cite this article: Krisztina Kovács, Ádám Simon, György Tibor Balogh, Tünde Tóth \& László Wojnárovits (2020): High-energy ionizing radiation-induced degradation of amodiaquine in dilute aqueous solution: radical reactions and kinetics, Free Radical Research, DOI:

10.1080/10715762.2020.1736579

To link to this article: https://doi.org/10.1080/10715762.2020.1736579

曲 Published online: 17 Mar 2020.

Submit your article to this journal $₫$

Џ Article views: 2

Q View related articles ๘

View Crossmark data $₫$ 


\title{
High-energy ionizing radiation-induced degradation of amodiaquine in dilute aqueous solution: radical reactions and kinetics
}

\author{
Krisztina Kovács ${ }^{a}$, Ádám Simon ${ }^{a, b}$, György Tibor Balogh ${ }^{c, d}$, Tünde Tóth ${ }^{a, b}$ and László Wojnárovits ${ }^{a}$

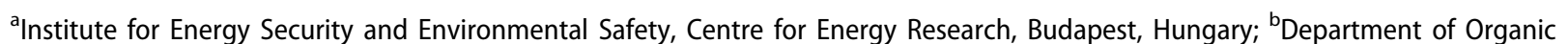

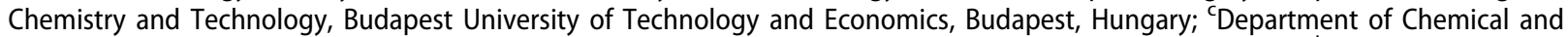 \\ Environmental Process Engineering, Budapest University of Technology and Economics, Budapest, Hungary; ${ }^{\mathrm{d}}$ Department of \\ Pharmacodynamics and Biopharmacy, University of Szeged, Szeged, Hungary
}

\begin{abstract}
The widely used antimalarial drug amodiaquine (AQ) contains a 7-Cl-quinoline unit, a substituted 4-aminophenol part connected through the amino group and a tertiary amine part. The 4-aminophenol unit can be easily oxidized through radical intermediates to iminoquinone. This reaction also takes place in vitro and in vivo enzymatic reactions. The reaction is expected to have an important role in degradation of $A Q$ in surface waters and also during degradation in advanced oxidation processes. In this paper by means of radiation chemical techniques the one-electron oxidation and reduction of $A Q$ were studied using transient kinetics, kinetics of $A Q$ degradation, formation and decay of end-products of radical reactions. The hydroxyl radicals were shown to add both to the quinoline $(\sim 38 \%)$ and aminophenol $(\sim 50 \%)$ parts via formation of hydroxycyclohexadienyl radicals and by $\mathrm{H}$-abstraction or by an electron removal from the tertiary amine part of the molecule ( 12\%). The dihydroxycyclohexadienyl radical formed on the aminophenol part is suggested to transform to aminophenoxy radical. The hydrated electrons can also effectively contribute to $\mathrm{AQ}$ degradation. Chemical oxygen demand and total organic carbon content investigations were also made in order to characterize the ionizing radiation-induced oxidation and mineralization. In aerated $0.1 \mathrm{mmol} \mathrm{dm}{ }^{-3}$ solution, at $2.5 \mathrm{kGy}$ absorbed dose $\mathrm{AQ}$ and its higher molecular mass degradation products demolished completely. Ionizing irradiation is a capable technique for degradation of $\mathrm{AQ}$ under both oxidative and reductive circumstances.
\end{abstract}

\section{ARTICLE HISTORY}

Received 6 November 2019

Revised 4 February 2020

Accepted 25 February 2020

\section{KEYWORDS}

Aminophenoxy radical; degradation efficiency; oneelectron oxidation; oxidative degradation;

pharmaceuticals

\section{Introduction}

The highly effective, and in Africa widely used, antimalarial drug amodiaquine (AQ) [1] may cause hepatotoxicity in man [2]. The molecule (with IUPAC name 4-[(7-chloroquinolin-4-yl)amino] - 2-[(diethylamino)methyl]phenol) contains a 7-Cl-quinoline unit, a substituted 4-aminophenol part connected through the amino group and a tertiary amine part (Figure 1). $A Q$ is a diprotic weak base with $\mathrm{p} K_{\mathrm{a}}$ at 8.14 and 7.08. These $\mathrm{p} K_{\mathrm{a}}$ 's correspond to the proton reaction involving the side chain terminal nitrogen and the first proton reaction involving the quinoline nucleus [3]. The 4-aminophenol unit can be easily oxidized through a radical intermediate to iminoquinone. The free radical has been reported to form also in in vitro and in vivo enzymatic reactions $[2,4]$. In the last decades, with the aim of removal of harmful organic contaminants from water/wastewater, a family of new techniques, called advanced oxidation processes is under developed.
In these processes inorganic radicals, mainly hydroxyl radicals $\left({ }^{\circ} \mathrm{OH}\right)$, are produced in photolytic, photocatalytic, radiolytic, etc., processes. These radicals attacking the organic molecules produce organic radicals. AQ is a frequently detected contaminant of wastewater in certain areas [5]. Thus studies on the radical reactions of $A Q$ have importance from both biochemical and environmental protection point of view.

Radiolysis techniques provide an excellent tool for studying radical reactions. In the radiolysis of water hydroxyl radical $\left({ }^{\circ} \mathrm{OH}\right)$, hydrated electron $\left(\mathrm{e}_{\mathrm{aq}}{ }^{-}\right)$and hydrogen atom $\left(\mathrm{H}^{\circ}\right)$ reactive radical intermediates (Reaction (1)) form with yields ( $G$-values) of $0.28,0.27$ and $0.06 \mu \mathrm{mol} \mathrm{J}^{-1}\left(\mathrm{~N}_{2}\right.$ saturated solution) [6]:

$$
\mathrm{H}_{2} \mathrm{O} \rightarrow \mathrm{OH}, \mathrm{e}_{\mathrm{aq}}{ }^{-}, \mathrm{H}^{\bullet}
$$

In the radiation chemical practice the ${ }^{\circ} \mathrm{OH}$ reactions are generally investigated in $\mathrm{N}_{2} \mathrm{O}$ saturated solution $\left(0.025 \mathrm{~mol} \mathrm{dm}^{-3}\right)$ in order to transform $\mathrm{e}_{\mathrm{aq}}{ }^{-}$to ${ }^{\circ} \mathrm{OH}$ in

CONTACT Krisztina Kovács kovacs.krisztina@energia.mta.hu Institute for Energy Security and Environmental Safety, Centre for Energy Research, Budapest, Hungary.

(C) 2020 Informa UK Limited, trading as Taylor \& Francis Group 


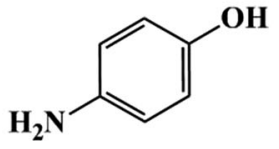

p-Aminophenol<smiles>CC(=O)Nc1ccc(O)cc1</smiles>

Acetaminophen (Paracetamol)<smiles>CCN(CC)Cc1cc(Nc2ccnc3cc(Cl)ccc23)ccc1O</smiles>

Amodiaquine

Figure 1. Structures of $p$-aminophenol, acetaminophen, and amodiaquine.

Reaction (2). The $\mathrm{e}_{\mathrm{aq}}{ }^{-}$reactions are usually studied in the presence of tert-butanol, which solute removes the hydroxyl radicals from the system (Reaction (3)). In the presence of dissolved $\mathrm{O}_{2}$ (air saturated solution), $\mathrm{O}_{2}{ }^{-\bullet} \%$ $\mathrm{HO}_{2}{ }^{\bullet}$ pair $\left(\mathrm{p} K_{\mathrm{a}}=4.8\right)$ forms in $\mathrm{e}_{\mathrm{aq}}{ }^{-}$and $\mathrm{H}^{\bullet}$ reactions (Reactions (4) and (5)). In this case, the main reacting agents are ${ }^{\bullet} \mathrm{OH}$ and $\mathrm{O}_{2}{ }^{\bullet-} / \mathrm{HO}_{2}{ }^{\bullet}$ :

$$
\begin{gathered}
\mathrm{e}_{\mathrm{aq}}{ }^{-}+\mathrm{N}_{2} \mathrm{O}+\mathrm{H}_{2} \mathrm{O} \rightarrow \mathrm{N}_{2}+\cdot{ }^{\bullet} \mathrm{OH}+\mathrm{OH}^{-} \\
\cdot \mathrm{OH}+\left(\mathrm{CH}_{3}\right)_{3} \mathrm{COH} \rightarrow \mathrm{H}_{2} \mathrm{O}+{ }^{\bullet} \mathrm{CH}_{2}\left(\mathrm{CH}_{3}\right)_{2} \mathrm{COH} \\
\mathrm{eqq}^{-}+\mathrm{O}_{2} \rightarrow \mathrm{O}_{2}{ }^{--} \\
\mathrm{H}^{\bullet}+\mathrm{O}_{2} \rightarrow \mathrm{HO}_{2}{ }^{\bullet}
\end{gathered}
$$

Using pulse radiolysis technique, the radical reactions of $A Q$ were studied by Bisby [2]. However, the radical reactions of its structural unit 4-aminophenol $[7,8]$ and also of the analgesic and antipyretic type drug molecule acetaminophen (paracetamol) [9-14] were investigated by several research groups. The hydroxyl radicals in their reactions with the aromatic molecules generally add to the conjugated ring, direct oxidation (i.e. picking up an electron from the attacked molecule) rarely occurs. In pulse radiolysis studies direct oxidation experiments applying $\mathrm{N}_{3}{ }^{\bullet}, \mathrm{Cl}_{2}{ }^{\bullet-},(\mathrm{SCN})_{2}{ }^{--}$or $\mathrm{Br}_{2}{ }^{--}$oneelectron oxidants were also conducted with all the three compounds. In these experiments such radical intermediates were observed whose characteristics were different from that of the phenoxyl radical (radical site on the oxygen atom) generally observed in oneelectron oxidation of phenol type molecules. In Reaction (6) the direct oxidation reaction is shown on the example of the $\mathrm{N}_{3}{ }^{\bullet}$ reaction with 4-aminophenol:

$$
\mathrm{N}_{3}{ }^{\bullet}+\mathrm{NH}_{2} \mathrm{C}_{6} \mathrm{H}_{4} \mathrm{OH} \rightarrow \mathrm{NH}_{2} \mathrm{C}_{6} \mathrm{H}_{4} \mathrm{O}^{\bullet}+\mathrm{H}^{+}+\mathrm{N}_{3}^{-}
$$

The phenoxyl radicals have characteristic absorption bands around $400 \mathrm{~nm}$ with well-defined fine structure and molar absorption coefficients of c.a. $3000 \mathrm{~mol}^{-1}$ $\mathrm{dm}^{3} \mathrm{~cm}^{-1}$ [15]. However, in the cases of the formerly mentioned compounds (e.g. 4-aminophenol), the band is shifted to longer wavelength by about $50 \mathrm{~nm}$ and the molar absorbance is higher by at least a factor of two. Tripathi devoted several papers to the radical intermediate that forms in 4-aminophenol reaction [7,16-18]. The structure of the radical was established to be more similar to that of a semiquinone than to that of the phenoxyl radical. It means a considerable part of spin density is concentrated on the nitrogen atom. The radical is also called aminophenoxy radical.

In the transient spectrum of the $\cdot \mathrm{OH}+$ acetaminophen reaction $1 \mu \mathrm{s}$ after the pulse (sol-

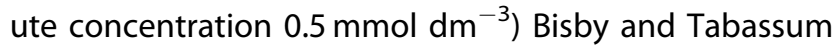
[10] detected the absorbance of the typical hydroxycyclohexadienyl intermediate with absorption maximum at $330 \mathrm{~nm}$. It means, in the reaction, as a first step, a radical adduct formed. However, $20 \mu$ s later a well resolved peak appeared with $\lambda_{\max }$ at $450 \mathrm{~nm}$ (Reaction (7)). This absorbance also appeared when acetaminophen was directly oxidized by $\mathrm{N}_{3}{ }^{\bullet}, \mathrm{Cl}_{2}{ }^{\bullet-}$ or $\mathrm{Br}_{2}{ }^{\bullet-}$ to aminophenoxy radical. In ${ }^{\circ} \mathrm{OH}$ reaction the $450 \mathrm{~nm}$ absorbance was also attributed to the aminophenoxy radical forming in dehydration of the hydroxycyclohexadienyl intermediate. The dehydration is fast process taking place on the few $\mu$ s timescale $[10,14,19]$. Bisby [2] suggested a similar mechanism for the ${ }^{\bullet} \mathrm{OH}+\mathrm{AQ}$ reaction:

$$
\begin{aligned}
& \mathrm{OH}+\mathrm{NH}_{2} \mathrm{C}_{6} \mathrm{H}_{4} \mathrm{OH} \rightarrow \mathrm{NH}_{2} \mathrm{C}_{6} \mathrm{H}_{4} \cdot(\mathrm{OH}) \mathrm{OH} \rightarrow \mathrm{NH}_{2} \mathrm{C}_{6} \mathrm{H}_{4} \mathrm{O}^{\bullet}+\mathrm{H}_{2} \mathrm{O} \\
& \text { hydroxycyclohexadienyl aminophenoxy }
\end{aligned}
$$

This work serves dual purposes. On the one hand, we determine further details of the radical reactions and suggest mechanism. On the other hand, for the purpose of water purification we follow the course of $\mathrm{AQ}$ decomposition and determine the efficiency in irradiation technology.

\section{Materials and methods}

$\mathrm{AQ}$ hydrochloride, methyl viologen dichloride hydrate (MV), 2,2'-azino-bis(3-ethylbenzothiazoline-6-sulfonic acid) diammonium salt (ABTS), hydroquinone $\left(\mathrm{H}_{2} \mathrm{Q}\right)$ were supplied by Sigma-Aldrich. $\mathrm{KH}_{2} \mathrm{PO}_{4}$ and $\mathrm{K}_{2} \mathrm{HPO}_{4}$ 

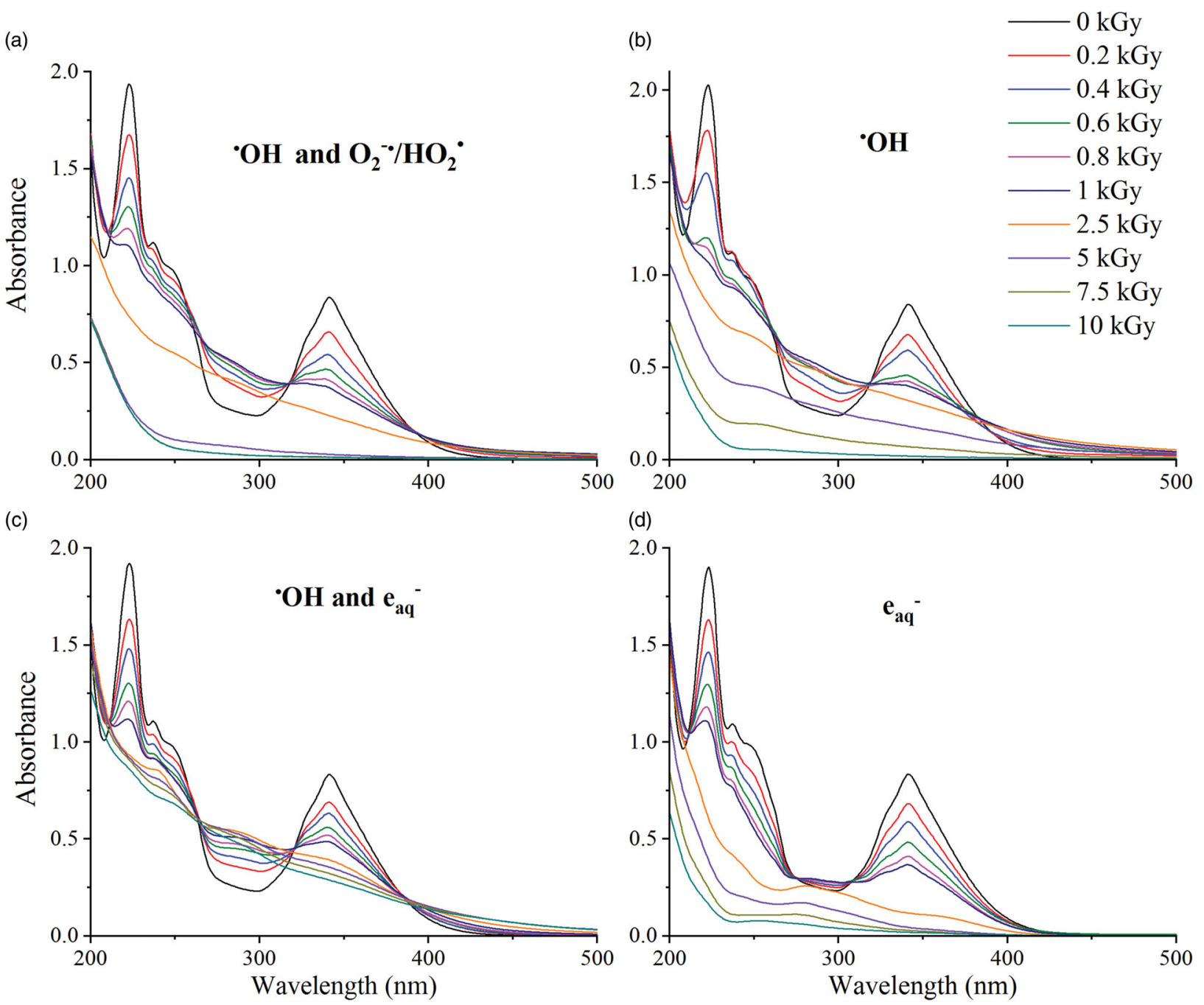

Figure 2. Absorption spectra of $0.1 \mathrm{mmol} \mathrm{dm} \mathrm{dm}^{-3}$ unirradiated and irradiated $A Q$ solutions under different conditions: in aerated (a), in $\mathrm{N}_{2} \mathrm{O}$ saturated (b), in $\mathrm{N}_{2}$ saturated (c) and in $\mathrm{N}_{2}$ saturated tert-butanol containing (d) solutions. In order to remain in the absorbance range where the Lambert-Beer low is expected to be obeyed two times dilution was applied.

for preparing buffers were provided by Reanal. Tertbutanol was obtained from Molar Chemicals.

The samples in the end-product experiments were irradiated in a panoramic type ${ }^{60} \mathrm{Co}-\gamma$ irradiation chamber with doses $0,0.2,0.4,0.6,0.8,1,2.5,5,7.5$ and 10 kGy under different conditions. The $\gamma$-irradiations were carried at room temperature at a dose rate of $10 \mathrm{kGy}$ $\mathrm{h}^{-1}$. The dose was determined using alcoholic chlorobenzene dosimetry [20]. The samples were saturated with $\mathrm{N}_{2} \mathrm{O}, \mathrm{N}_{2}$ or air. In some experiments they were gently bubbled during irradiations in order to avoid oxygen depletion. The initial AQ concentration was $0.1 \mathrm{mmol} \mathrm{dm^{-3 }}$. The samples before and after irradiation were characterized by using a JASCO 550 ultraviolet-visible (UV-vis) spectrophotometer in $1 \mathrm{~cm}$ cell and applying appropriate dilutions before taking the spectra.
The transient intermediates of degradation reactions were investigated by the pulse radiolysis technique. Our microsecond pulse radiolysis experiments were performed using $4 \mathrm{MeV}$ accelerated electrons with electron pulse length of $800 \mathrm{~ns}$ and utilizing kinetic spectrophotometric detection with $1 \mathrm{~cm}$ path length cell [21]. Pulse dosimetry was carried out with air saturated, $1 \times 10^{-2} \mathrm{~mol} \mathrm{dm}^{-3} \mathrm{KSCN}$ solutions monitoring the transient product, $\left((\mathrm{SCN})_{2}{ }^{--}\right)$at $480 \mathrm{~nm}\left(\lambda_{\max }\right)$ and calculating the dose with a molar absorbance of $7580 \mathrm{~mol}^{-1}$ $\mathrm{dm}^{3} \mathrm{~cm}^{-1}$ [22]. The dose/pulse values were $20 \mathrm{~Gy} /$ pulse. Because $A Q$ exhibits considerable light absorption in the near UV range an optical filter was used to decrease the effect of bleaching below $400 \mathrm{~nm}$.

In order to identify and quantify the participating free radicals (e.g. $\alpha$-aminoalkyl) with different reduction potentials, redox titration measurements were 

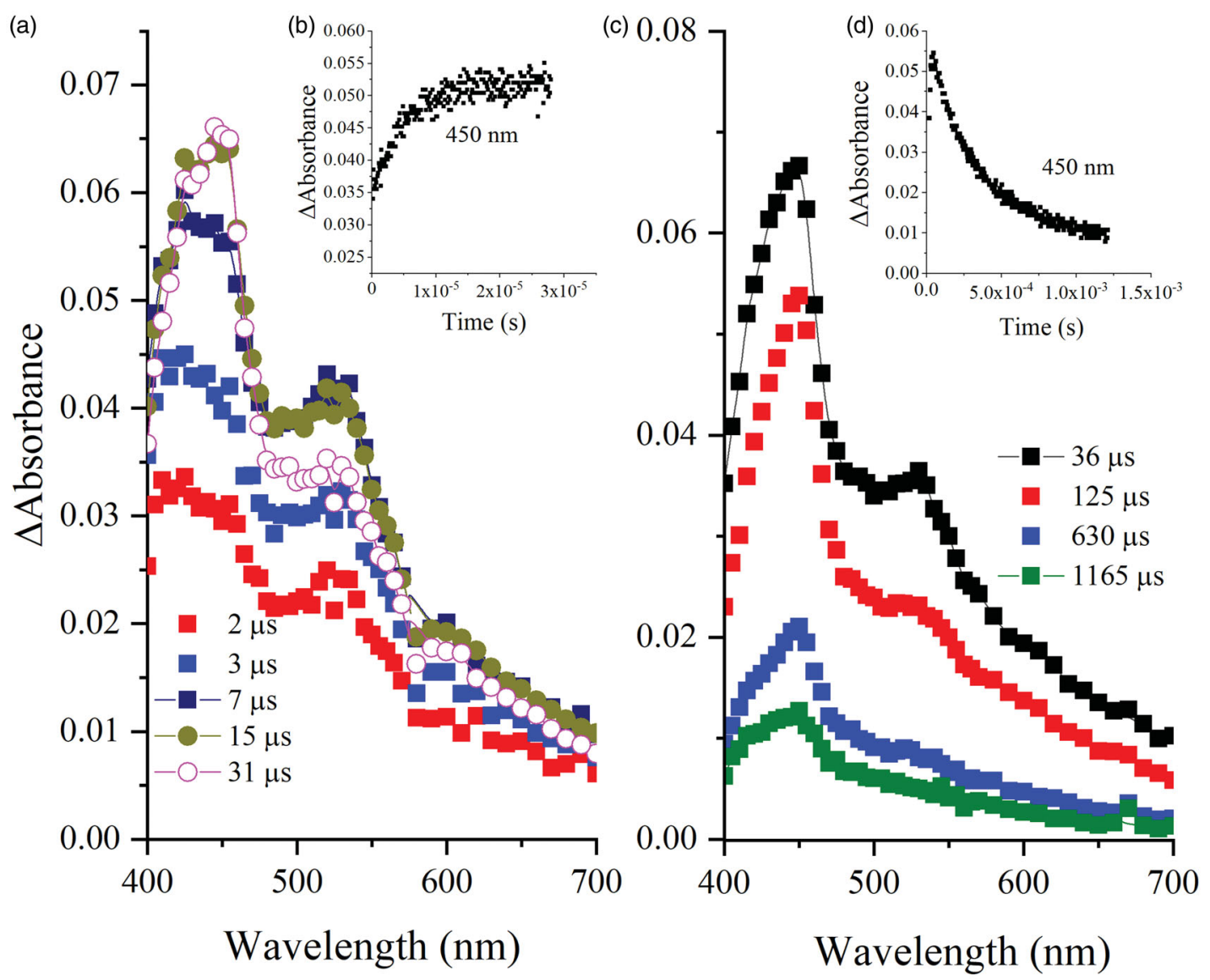

Figure 3. Transient absorption spectra of $A Q$ in $0.1 \mathrm{mmol} \mathrm{dm}{ }^{-3} \mathrm{~N}_{2} \mathrm{O}$ saturated solution containing $1 \mathrm{mmol}^{\mathrm{dm}^{-3}}$ phosphate buf-

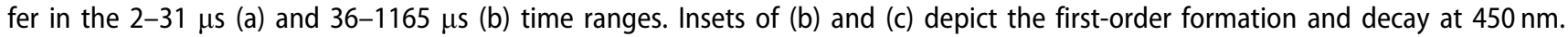

conducted. Methyl viologen $\left(\mathrm{MV}, \mathrm{E}^{\circ}\left(\mathrm{MV}^{2+} / \mathrm{MV}^{\bullet+}\right)=\right.$ $-0.448 \mathrm{~V}$ vs. NHE) was applied for the detection of reducing $\alpha$-aminoalkyl radicals [23]. $\mathrm{MV}^{\bullet+}$ absorbs at $600 \mathrm{~nm}$ with $\varepsilon_{600}=11,850 \mathrm{~mol}^{-1} \mathrm{dm}^{3} \mathrm{~cm}^{-1}$ [24]. Oxidizing, nitrogen-centered radicals can be monitored with $A B T S$ and $\mathrm{H}_{2} \mathrm{Q}\left(\mathrm{E}^{\circ}\left(\mathrm{ABTS}^{\bullet+} / \mathrm{ABTS}\right)=0.680 \mathrm{~V}[25]\right.$ and $\left.\mathrm{E}^{\circ}\left(\mathrm{Q}^{\bullet}-\mathrm{Q}_{2}{ }^{-}\right)=0.459 \mathrm{~V}[23]\right)$. The forming radicals were detected at 415 and $430 \mathrm{~nm}\left(\varepsilon_{415}=36,000 \mathrm{~mol}^{-1}\right.$ $\mathrm{dm}^{3} \mathrm{~cm}^{-1}$ and $\varepsilon_{430}=7200 \mathrm{~mol}^{-1} \mathrm{dm}^{3} \mathrm{~cm}^{-1}$ ), respectively $[26,27]$. Based on the absorbances of forming radicals the yields of reducing/oxidizing radicals were calculated.

The removal of efficiency was evaluated by using Agilent 1200 LC and Agilent 6410 MS devices. The separation was carried out on a Kinetex XB-C18 column $(100 \times 2.1 \mathrm{~mm}$, particle size $2.6 \mu \mathrm{m})$ at $25^{\circ} \mathrm{C}$. The mobile phase was the mixture of $0.1 \%$ formic acid aqueous solution (A) and acetonitrile (B). Gradient elution was performed as follows: the starting composition was $5 \%$ B for $1 \mathrm{~min}$, then increased to $10 \%$ in $0.5 \mathrm{~min}$, kept this condition for $9 \mathrm{~min}$, than increased to $50 \%$ in $0.5 \mathrm{~min}$. The measurements were conducted in positive ionization mode.
The time (dose) dependence of degradation was characterized by the sum parameters, chemical oxygen demand (COD) and total organic carbon (TOC) content measurements used in environmental analysis of water samples. COD values were assessed based on ISO Standard 6060:1989 by a Behrotest TRS 200 COD system. Shimadzu TOC-LCSH/CSN was used for the determination of TOC.

\section{Results and discussion}

\section{UV-vis absorption spectra of amodiaquine in $\gamma$-radiolysis and pulse radiolysis experiments}

The absorption spectra of samples irradiated by $\gamma$-rays in air, $\mathrm{N}_{2} \mathrm{O}$ and $\mathrm{N}_{2}$ (without and with tert-butanol added) saturated samples are shown in Figure 2 (a-d). Under these conditions the reactive intermediates are ${ }^{\bullet} \mathrm{OH}+\mathrm{O}_{2}{ }^{-\bullet} / \mathrm{HO}_{2}{ }^{\bullet}, \cdot{ }^{\bullet} \mathrm{OH}, \cdot{ }^{\bullet} \mathrm{OH}+\mathrm{e}_{\mathrm{aq}}{ }^{-}$, and $\mathrm{e}_{\mathrm{aq}}{ }^{-}$, respectively. The wide band between 300 and $400 \mathrm{~nm}$ in the UV-vis spectrum exhibits $\lambda_{\max }$ at $341 \mathrm{~nm}$ with $\varepsilon_{\max }$ of $16,400 \mathrm{~mol}^{-1} \mathrm{dm}^{3} \mathrm{~cm}^{-1}$. The absorbance gradually 


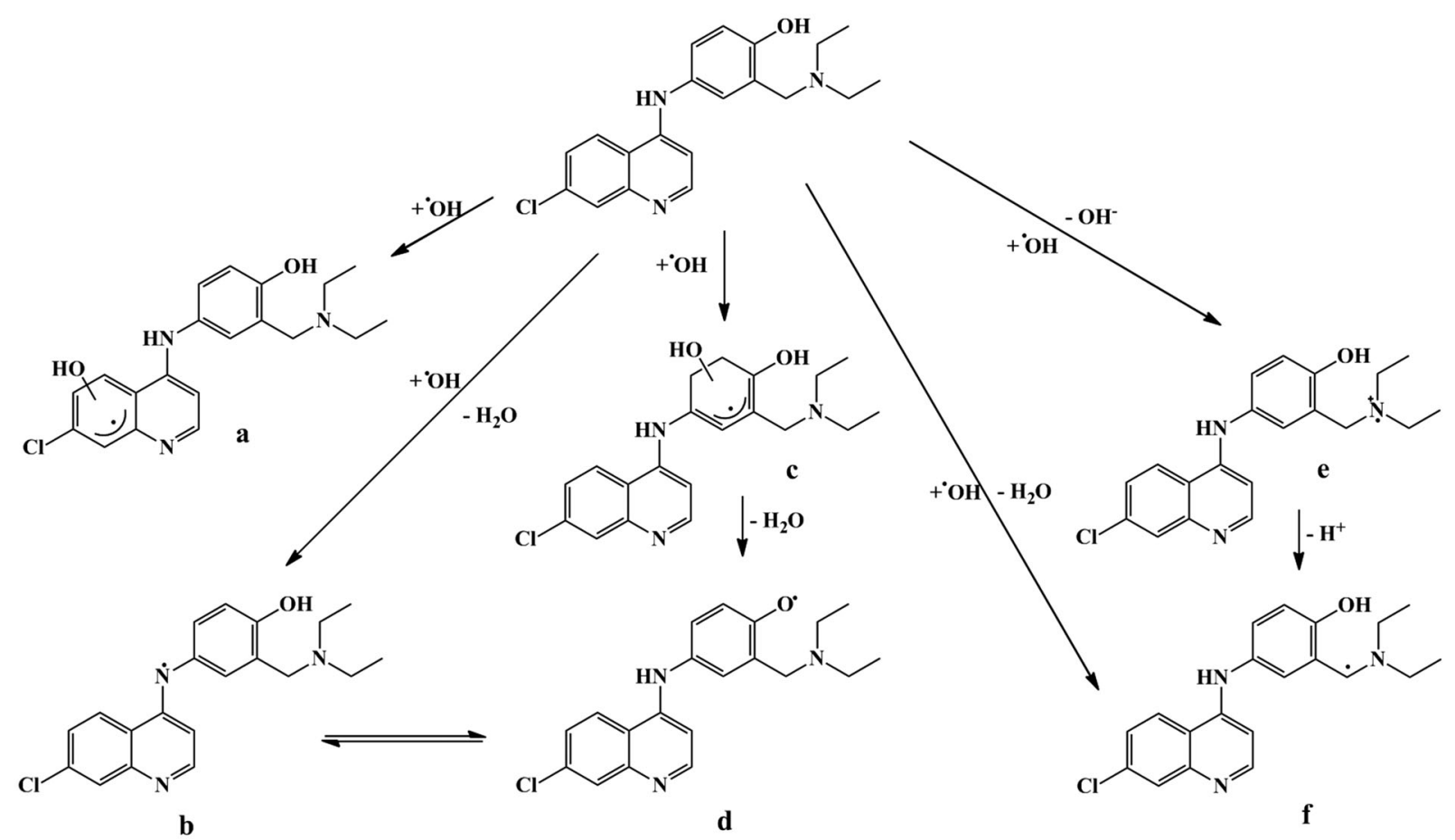

Scheme 1. ${ }^{\bullet} \mathrm{OH}$ reactions with $A Q$.

decreases with the increasing dose and disappears at $2.5 \mathrm{kGy}$.

In air, $\mathrm{N}_{2}$ and $\mathrm{N}_{2} \mathrm{O}$ saturated solutions the ${ }^{\circ} \mathrm{OH}$ reactions are dominant. ${ }^{\circ} \mathrm{OH}$ forms with yields: $0.28,0.56$ and $0.28 \mu \mathrm{mol} \mathrm{J}{ }^{-1}$, respectively. The transient intermediates in the ${ }^{\bullet} \mathrm{OH}+\mathrm{AQ}$ reaction were studied using pulse radiolysis in $\mathrm{N}_{2} \mathrm{O}$ saturated solution (Figure 3 ). In the 400-700 nm wavelength range two bands can be distinguished: a strong band at $\sim 450 \mathrm{~nm}$ and a smaller one at $525 \mathrm{~nm}$.

- $\mathrm{OH}$ is expected to react with the $\mathrm{Cl}$-quinoline, 4aminophenol and also with the tertiary amine part of AQ. Based on the measured rate constant $\left(9.0 \times 10^{9} \mathrm{~mol}^{-1} \mathrm{dm}^{3} \mathrm{~s}^{-1}\right)$, at $0.1 \mathrm{mmol} \mathrm{dm}{ }^{-3} \mathrm{AQ}$ concentration the ${ }^{\bullet} \mathrm{OH}$ reaction is completed in c.a. $3 \mu$ s. The radical adducts on $\mathrm{Cl}$-quinoline ( $\mathrm{a}$, Scheme 1 ) and 4-aminophenol (c) parts of $A Q$ are expected to exhibit transient absorption between 300 and $400 \mathrm{~nm}$ as it is typical for aromatic adduct (hydroxycyclohexadienyl) radicals [8]. Due to the strong absorbance of $A Q$ in this range, we did not take the transient spectrum at wavelengths below $400 \mathrm{~nm}$.

- $\mathrm{OH}$ is assumed to react with addition to both rings of the $\mathrm{Cl}$-quinoline part $[28,29]$. The reaction taking place on this part is supported by the UV-vis spectra of $\gamma$-irradiated solutions. In cases when ${ }^{\circ} \mathrm{OH}$ played a key role in degradation the $241 \mathrm{~nm}$ peak shifted to shorter wavelength due dehalogenation. Similar shift was also observed in ${ }^{\circ} \mathrm{OH}$-induced dehalogenation of $\mathrm{Cl}$-substituted phenylureas, e.g. monuron and diuron [30,31].
We expect a moderately fast ${ }^{\bullet} \mathrm{OH}$ reaction with the $\mathrm{Cl}$ quinoline part of $\mathrm{AQ}$ due to the deactivating electronegative $\mathrm{Cl}$-and $\mathrm{N}$-atoms.

The absorbance above $400 \mathrm{~nm}$ can be attributed to reactions on the 4-aminophenol part of $A Q$ in agreement with results on 4-aminophenol and acetaminophen $[2,8,14]$. ${ }^{\circ} \mathrm{OH}$ reaction in these molecules produces 4-aminophenoxy radical with $\lambda_{\max } \approx 440 \mathrm{~nm}$ and $\varepsilon_{\max } \approx 5000 \mathrm{~mol}^{-1} \mathrm{dm}^{3} \mathrm{~cm}^{-1}[7,8]$. The increasing absorbance above $400 \mathrm{~nm}$ after the $\mathrm{AQ}+{ }^{\circ} \mathrm{OH}$ reaction is completed is due to transformation of the first formed hydroxycyclohexadienyl radical (c, Scheme 1) to aminophenoxy radical (d) with a rate constant of $2 \times 10^{5} \mathrm{~s}^{-1}$. The molar absorbance of this radical at $460 \mathrm{~nm}$, based on $A Q$ reaction with the directly oxidizing $\mathrm{N}_{3}{ }^{\bullet}$ was suggested to be $14,000 \mathrm{~mol}^{-1} \mathrm{dm}^{3} \mathrm{~cm}^{-1}$ [2]. Using this molar absorbance and the absorbance measured in our experiment, $\sim 50 \%$ of the primarily formed organic radicals transform to aminophenoxy radical.

At the $\mathrm{pH}$ of our investigations $(\mathrm{pH}=6.8) \sim 5 \%$ of the $\mathrm{N}$-atoms on the trialkyl amine part of $A Q$ are deprotonated. The rate constant of reaction with deprotonated triethylamine is reported to be high, $1.0 \times 10^{10} \mathrm{~mol}^{-1} \mathrm{dm}^{3} \mathrm{~s}^{-1}$, while with the protonated form it is low, $3.8 \times 10^{8} \mathrm{~mol}^{-1} \mathrm{dm}^{3} \mathrm{~s}^{-1}$ [32]. Due to the low percentage, the reaction with the deprotonated form gives low contribution to the overall degradation. In the reaction between ${ }^{\circ} \mathrm{OH}$ and the triethylamine part of $A Q \alpha$-aminoalkyl radicals are expected (f, Scheme 1 ) 

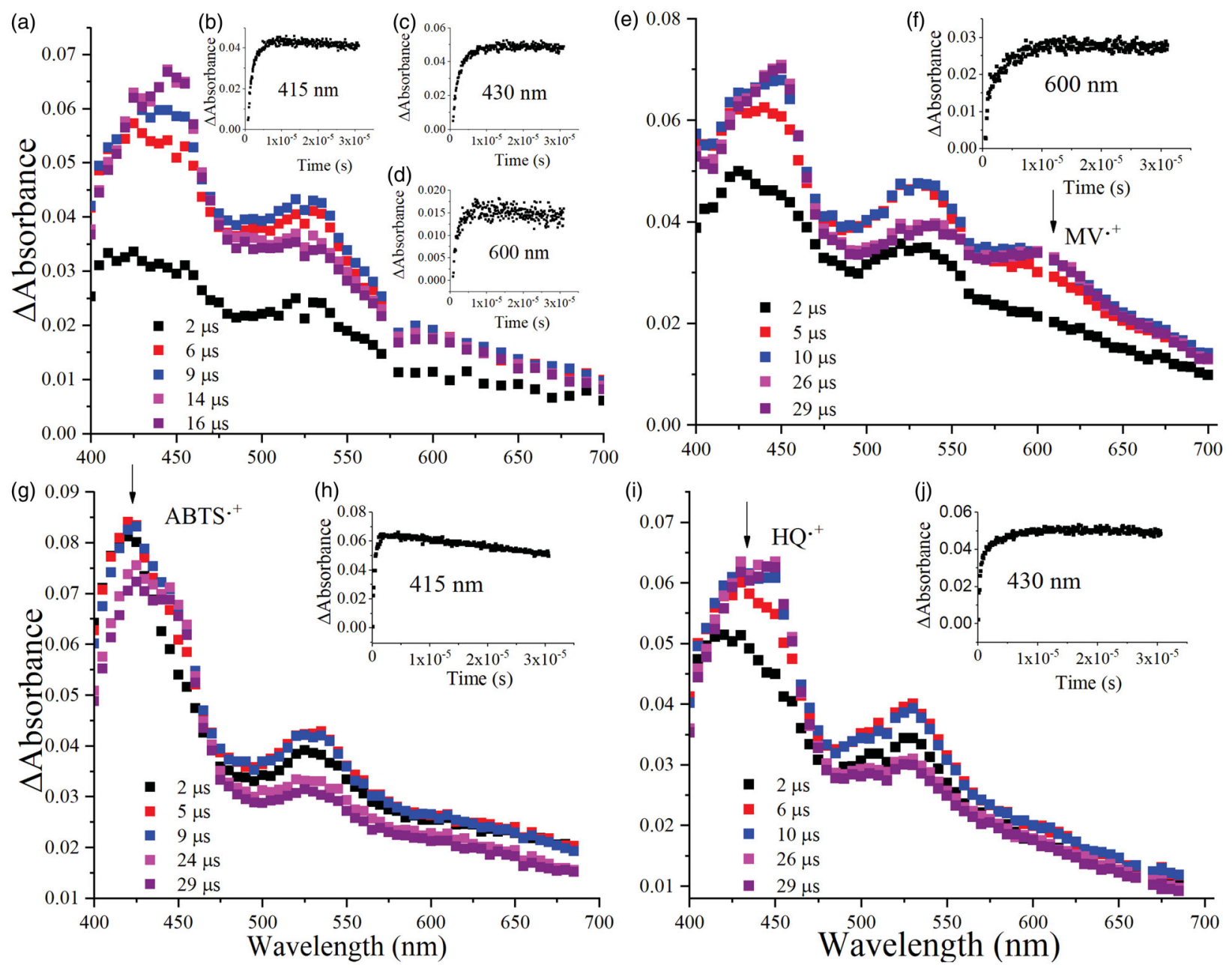

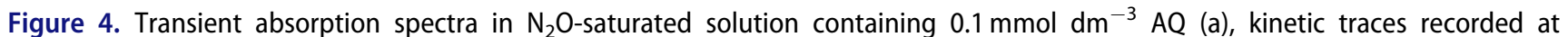
$415 \mathrm{~nm}$ (b), at $430 \mathrm{~nm}$ (c) and $600 \mathrm{~nm}$ (d). Redox titration spectra in $\mathrm{N}_{2} \mathrm{O}$ saturated solution containing $0.4 \mathrm{mmol}^{-3} \mathrm{AQ}$ and $0.1 \mathrm{mmol} \mathrm{dm}{ }^{-3} \mathrm{MV}$ (e), $0.4 \mathrm{mmol} \mathrm{dm} \mathrm{m}^{-3} \mathrm{AQ}$ and $0.07 \mathrm{mmol} \mathrm{dm} \mathrm{dm}^{-3} \mathrm{ABTS}(\mathrm{g}), 0.4 \mathrm{mmol} \mathrm{dm} \mathrm{m}^{-3} \mathrm{AQ}$ and $0.07 \mathrm{mmol} \mathrm{dm}^{-3} \mathrm{HQ}$ (i). The insets of (e), (g) and (i) show kinetic curves recorded at $600 \mathrm{~nm}(\mathrm{f}), 415 \mathrm{~nm}(\mathrm{~h})$, and $430 \mathrm{~nm}(\mathrm{j})$.

[32,33]. These radicals may form by $\mathrm{H}$-abstraction or by deprotonation of the $\mathrm{R}_{1} \mathrm{~N}^{+}\left(\mathrm{C}_{2} \mathrm{H}_{5}\right)_{2}$ cation that can be produced in direct oxidation.

To get a comprehensive picture about ${ }^{\bullet} \mathrm{OH}$-induced chemistry of $A Q$, the yields of $\alpha$-aminoalkyl and nitrogen-centered radicals were quantified in redox titration experiments at $0.4 \mathrm{mmol} \mathrm{dm}^{-3} \mathrm{AQ}$ concentration (Figure 4). $\alpha$-aminoalkyl radicals as strong reducing species react with $\mathrm{MV}^{2+}$ via electron transfer $[33,34] . \mathrm{MV}^{\bullet+}$ was recorded with a yield of $\sim 0.068 \mu \mathrm{mol} \mathrm{J}^{-1}$. ${ }^{\circ} \mathrm{OH}$ may also react with the triethylamine part of $A Q$ by producing $\mathrm{N}$-centered oxidizing aminium $\left(\mathrm{R}_{3} \mathrm{~N}^{\bullet+}\right)$ and aminyl $\left(\mathrm{R}_{2} \mathrm{~N}^{\bullet}\right)$ radicals. $\mathrm{ABTS}\left(\mathrm{R}_{3} \mathrm{~N}^{\bullet+}\right)$ and $\mathrm{H}_{2} \mathrm{Q}\left(\mathrm{R}_{2} \mathrm{~N}^{\bullet}\right)$ were applied for the quantification of nitrogen-centered radicals. The results showed that aminyl radicals were not produced in the system. Aminium radicals (e, Scheme 1) were produced, albeit with low, $\sim 10 \%$ yield. These radicals may transform entirely to $\alpha$-aminoalkyl radicals (Scheme 1).

The $\mathrm{e}_{\mathrm{aq}}{ }^{-}$reaction was studied in $\mathrm{N}_{2}$ saturated solutions containing $0.5 \mathrm{~mol} \mathrm{dm}^{-3}$ tert-butanol. Upon $\gamma$-irradiation the intensity of the $241 \mathrm{~nm}$ band in the UV-vis spectrum (Figure 2(d)) decreased without wavelength shift. In the transient spectrum (Figure 5) the strong absorbance in the $500-700 \mathrm{~nm}$ range (the absorbance of $\mathrm{e}_{\mathrm{aq}}{ }^{-}\left(\lambda_{\max } \approx 720 \mathrm{~nm}, \varepsilon_{\max } \approx\right.$ $\left.\left.20,000 \mathrm{~mol}^{-1} \mathrm{dm}^{3} \mathrm{~cm}^{-1}[6,35]\right)\right)$ decayed within $2 \mu \mathrm{s}$, and a wide band remained with lower intensity. The latter is attributed to the $A Q$ electron adduct. The rate constant of $\mathrm{e}_{\mathrm{aq}}{ }^{-}+\mathrm{AQ}$ reaction was found to be $1.6 \times 10^{10} \mathrm{~mol}^{-1} \mathrm{dm}^{3} \mathrm{~s}^{-1}$. It is higher than measured for quinoline or 1-chloronaphthalene $\left(7.1 \times 10^{9}\right.$ and $1.4 \times 10^{10} \mathrm{~mol}^{-1} \mathrm{dm}^{3} \mathrm{~s}^{-1}$, respectively, $\left.[36,37]\right)$ due to the presence of $\mathrm{Cl}$ and $\mathrm{N}$ electronegative atoms in the 


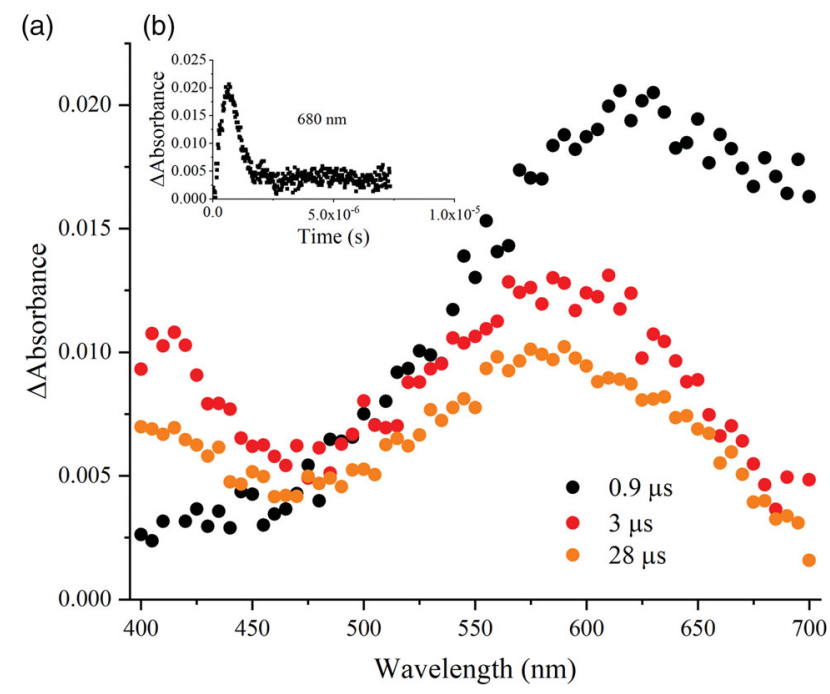

Figure 5. Transient absorption spectrum of $\mathrm{AQ}$ taken in $0.1 \mathrm{mmol} \mathrm{dm} \mathrm{dm}_{2}^{-3}$ saturated solution containing $0.5 \mathrm{~mol}$ $\mathrm{dm}^{-3}$ tert-butanol and also $1 \mathrm{mmol} \mathrm{dm}^{-3}$ phosphate buffer in the $0.9-28 \mu \mathrm{s}$ time range. Inset displays a kinetic trace at $680 \mathrm{~nm}(\mathrm{~b})$.

$\mathrm{Cl}$-quinoline part. $\mathrm{e}_{\mathrm{aq}}{ }^{-}$is expected to react preferentially with this part of $A Q$ accommodating on the pyridine ring. Zhu et al. [36] published a similar electron adduct spectrum for quinoline molecule as we found for $A Q$. The reactivity with the aminophenol part is probably low. $p$-Aminophenol and acetaminophen react with $\mathrm{e}_{\mathrm{aq}}{ }^{-}$with rate constants of $2.5 \times 10^{8}$ and $5 \times 10^{8} \mathrm{~mol}^{-1} \mathrm{dm}^{3} \mathrm{~s}^{-1}$, respectively $[8,14]$; the rate constants of alkylamines are also in the few times $10^{9} \mathrm{~mol}^{-1} \mathrm{dm}^{3} \mathrm{~s}^{-1}$ range [35].

\section{Removal efficiency of amodiaquine}

To get a more reliable and complementary picture about the removal of $A Q$ at each stage of treatment liquid chromatographic separation with mass spectrometry detection (LC-MS), COD, and TOC measurements were conducted.

The samples containing $0.1 \mathrm{mmol} \mathrm{dm} \mathrm{d}^{-3} \mathrm{AQ}$ were irradiated in aerated solutions (Figure 6). AQ is a highly polar compound with $\log D=-1.4$ (at pH 5) [38]. AQ eluted at $8.49 \mathrm{~min}$, it was detected using the molecular ion $\left([\mathrm{M}+\mathrm{H}]^{+}\right)$of 356 . The drug concentration decreased gradually with increasing absorbed dose (Figure 6, inset). At $2.5 \mathrm{kGy}$ dose no $\mathrm{AQ}$ and its degradation products were detected in the solutions.

Changes in COD values may characterize the rate of oxidation $(\Delta C O D /$ dose), while changes in TOC give information on the rate of mineralization. The initial

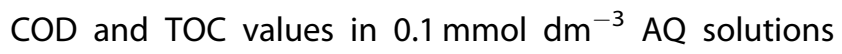
were measured as $79 \mathrm{mg}\left(\mathrm{O}_{2}\right) \mathrm{dm}^{-3}$ and $31 \mathrm{mg}$ (C) $\mathrm{dm}^{-3}$, these values are close to the ones calculated

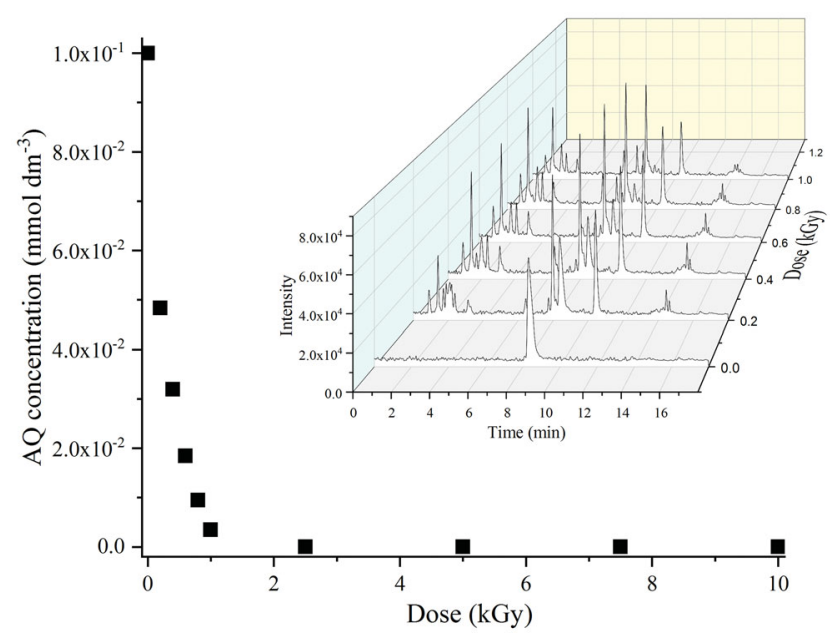

Figure 6. Decrease of $A Q$ concentration in aerated solutions. Inset: chromatogram of $A Q$ and its degradation products.

based on the molecular formula. The COD and TOC values decreased gradually with absorbed dose (Figure 7).

Based on changes in COD values, degradation of $A Q$ can be described by two different linear stages. At low doses $(0-3 \mathrm{kGy})$ the initial $\Delta \mathrm{COD} /$ dose slope was $6.6 \times 10^{-3} \mathrm{mg} \mathrm{dm}^{-3} \mathrm{~Gy}^{-1}$, then, above $3 \mathrm{kGy}$, the oxidation rate decreased to $1.8 \times 10^{-3} \mathrm{mg} \mathrm{dm}^{-3} \mathrm{~Gy}^{-1}$. In the first stage the degradation of the initial molecule and its higher molecular mass organic transformation products takes place. At c.a. $2.5 \mathrm{kGy}$ they disappear from the solution (Figures 2(a) and 5). The higher molecular mass products are expected to decay to small molecular mass carboxylic acids, aldehydes and ketones [39] these molecules are known to be oxidized very slowly. The decrease of TOC with absorbed dose was almost linear, the rate of mineralization was $1.6 \times 10^{-3} \mathrm{mg} \mathrm{dm}^{-3}$ $\mathrm{Gy}^{-1}$. The initial rate of oxidation and mineralization are different, the decrease in the COD value at $5 \mathrm{kGy}$ dose was about $50 \%$, while in TOC this decrease was only $30 \%$.

The oxidation efficiency $(E)$ is defined as the ratio of the number of $\mathrm{O}_{2}$ molecules used for oxidation (calculated from $\Delta \mathrm{COD} /$ dose values) and the number of ${ }^{\circ} \mathrm{OH}$ injected into the solution [40]. When this value is 1 , every ${ }^{\bullet} \mathrm{OH}$ leads to incorporation of one $\mathrm{O}_{2}$ molecule, i.e. the attack of the one-electron oxidant ${ }^{\bullet} \mathrm{OH}$ leads to four electron oxidations of the organic molecules. Such high values were observed when the organic radical formed in ${ }^{\circ} \mathrm{OH}$ reaction readily reacted with dissolved $\mathrm{O}_{2}$. If the reactivity of the organic radical with $\mathrm{O}_{2}$ was low, $E$ was well below 1 . Aminophenoxy type radicals practically does not react with $\mathrm{O}_{2}[10,40]$.

For $p$-aminophenol and acetaminophen (also in air saturated solutions) $E=0.55$ and 0.4 , respectively, were measured [40]. Based on the initial $\Delta \mathrm{COD} /$ dose slope 


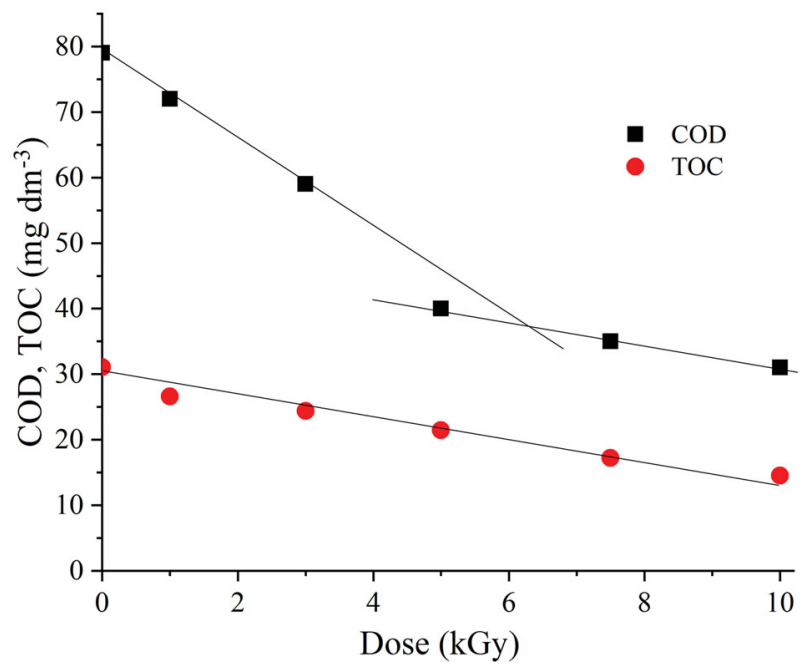

Figure 7. Dose dependence of COD and TOC values in aerated, $0.1 \mathrm{mmol} \mathrm{dm}{ }^{-3} \mathrm{AQ}$ solution.

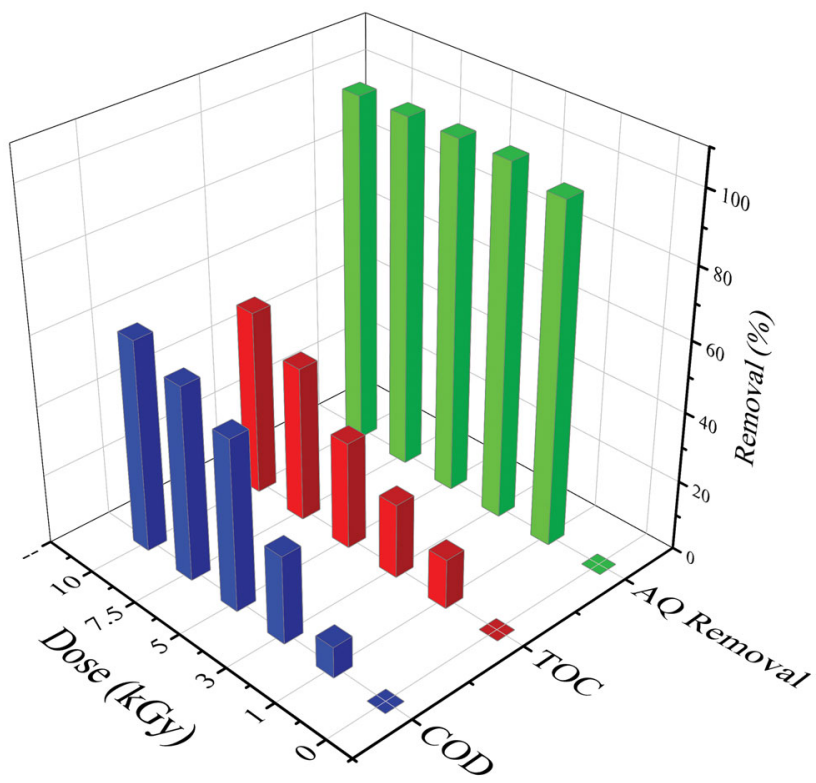

Figure 8. Comparison of removal percentages of $A Q, T O C$, and COD.

(Figure 7) $E$ was found to be 0.7 for $A Q$. This value for $A Q$ is higher than reported for the two previously mentioned compounds, reflecting more efficient oxidation. In all three cases aminophenoxy type radicals were suggested to be produced in reaction with ${ }^{\circ} \mathrm{OH}$. $A Q$ is a more complex molecule than $p$-aminophenol and acetaminophen, beyond the central $p$-aminophenol unit it contains also quinoline and tertiary amine parts. Formerly ${ }^{\circ} \mathrm{OH}$ was shown to attack these parts also forming carbon atom centered radicals, which may readily react with dissolved $\mathrm{O}_{2}$. The higher rate of oxidation of $A Q$ may be related to these reactions.

A comparison of LC-MS, COD and TOC results is shown on the Figure 8. At $10 \mathrm{kGy}$ dose $A Q$ and its main degradation products were entirely consumed. However, the mentioned small molecular mass oxidized organic molecules were yet present in the solution. This high absorbed dose resulted in $\sim 60 \%$ COD removal and $\sim 50 \%$ TOC removal in course of $\mathrm{AQ}$ decomposition.

\section{Conclusion}

This study provided a detailed insight into the radical reactions and decomposition of $\mathrm{AQ}$ under oxidative and reductive conditions. ${ }^{\circ} \mathrm{OH}$ adds to both $\mathrm{Cl}$-quinoline $(\sim 38 \%)$ and aminophenol $(\sim 50 \%)$ parts via formation of hydroxycyclohexadienyl radicals and by $\mathrm{H}$ abstraction or by an electron removal from the tertiary amine part of the molecule ( 12\%). The hydroxycyclohexadienyl radical formed on the aminophenol part is suggested to transform to aminophenoxy radical. The presence of electron withdrawing chlorine atom increases the reactivity of $\mathrm{e}_{\mathrm{aq}}{ }^{-}$towards $\mathrm{AQ}$ $\left(1.6 \times 10^{10} \mathrm{~mol}^{-1} \mathrm{dm}^{3} \mathrm{~s}^{-1}\right)$ compared to other N-containing molecules such as aminophenols. In aerated $0.1 \mathrm{mmol} \mathrm{dm}{ }^{-3}$ solution, at $2.5 \mathrm{kGy}$ absorbed dose $\mathrm{AQ}$ and the higher molecular mass degradation products detected by LC-MS disappeared completely. lonizing irradiation is a capable technique for degradation of $A Q$ under both oxidative and reductive circumstances.

\section{Disclosure statement}

No potential conflict of interest was reported by the author(s).

\section{Funding}

The authors thank International Atomic Energy Agency (IAEA) for support [Coordinated Research Project F23034, Contract no: 23754].

\section{References}

[1] Tilley L, Loria P, Foley M. Chloroquine and other quinoline antimalarials. In: Rosenthal PJ, ed. Antimalarial chemotherapy, mechanism of action, resistance and new directions in drug discovery. New York: Springer Science; 2001. p. 87-89.

[2] Bisby $\mathrm{RH}$. Reactions of a free radical intermediate in the oxidation of amodiaquine. Biochem Pharmacol. 1990;39(12):2051-2055.

[3] Hawley SR, Bray PG, Park BK, et al. Amodiaquine accumulation in Plasmodium falciparum as a possible explanation for its superior antimalarial activity over chloroquine. Mol Biochem Parasitol. 1996;80(1):15-25. 
[4] Bisby $\mathrm{RH}$. Pulse radiolysis, free radicals and antiparasitic drugs. Parasitol Today. 1990;6(3):84-88.

[5] Tella AC, Owalude SO, Olatunji SJ, et al. Synthesis of zinc-carboxylate metal-organic frameworks for the removal of emerging drug contaminant (amodiaquine) from aqueous solution. J Environ Sci. 2018;64: 264-275.

[6] Buxton GV, et al. An overview of the radiation chemistry of liquids. In: Spotheim-Maurizot M, Mostafavi M, Douki T, editors. Radiation chemistry: From basics to applications in material and life sciences. France: EDP Sciences; 2008. p. 3-16.

[7] Tripathi GNR, Schuler RH. Resonance Raman studies of pulse radiolytically produced $p$-aminophenoxyl radical. J Phys Chem. 1984;88(9):1706-1710.

[8] Dwibedy P, Dey GR, Naik DB, et al. Radiation-induced redox reactions of $2-, 3-$ and 4-amino-phenols in aqueous solutions. Radiat Phys Chem. 2005;74(1): 12-20.

[9] Fischer V, West PR, Harman LS, et al. Free-radical metabolites of acetaminophen and a dimethylated derivative. Environ Health Perspect. 1985;64:127-137.

[10] Bisby RH, Tabassum N. Properties of the radicals formed by one-electron oxidation of acetaminophen--a pulse radiolysis study. Biochem Pharmacol. 1988;37(14):2731-2738.

[11] Andreozzi R, Caprio V, Marotta R, et al. Paracetamol oxidation from aqueous solutions by means of ozonation and $\mathrm{H}_{2} \mathrm{O}_{2} / \mathrm{UV}$ system. Water Res. 2003;37(5): 993-1004.

[12] Yang L, Yu LE, Ray MB. Degradation of paracetamol in aqueous solutions by $\mathrm{TiO}_{2}$ photocatalysis. Water Res. 2008;42(13):3480-3488.

[13] Yang L, Yu LE, Ray MB. Photocatalytic oxidation of paracetamol: dominant reactants, intermediates, and reaction mechanisms. Environ Sci Technol. 2009;43(2): 460-465.

[14] Szabó L, Tóth T, Homlok R, et al. Radiolysis of paracetamol in dilute aqueous solution. Radiat Phys Chem. 2012;81(9):1503-1507.

[15] Wojnárovits L, Kovács A, Földiák G. Spectral characteristics of monosubstituted phenoxyl radicals. Radiat Phys Chem. 1997;50(4):377-379.

[16] Sun Q, Tripathi GNR, Schuler RH. Time-resolved resonance Raman spectroscopy of $p$-aminophenol radical cation in aqueous solution. J Phys Chem. 1990;94(16): 6273-6277.

[17] Tripathi GNR, Schuler RH. Structure of the $p$-aminophenoxyl radical. Faraday Trans. 1993;89(23): 4177-4180.

[18] Tripathi G. Proton reactivity and electronic structure of phenoxyl radicals in water. J Phys Chem A. 1998; 102(13):2388-2397.

[19] Ismail FMD, Drew MGB, Navaratnam S, et al. A pulse radiolysis study of free radicals formed by one-electron oxidation of the antimalarial drug pyronaridine. Res Chem Intermed. 2009;35(4):363-377.

[20] International Organization for Standardization, American Society for Testing and Materials (ISO/ ASTM). Practice for use of the ethanol-chlorobenzene dosimetry system. Standard No. ISO/ASTM;51538. ISO/ ASTM.
[21] Földiák G, Hargittai P, Kaszanyiczki L, et al. A computer controlled pulse radiolysis laboratory. J Radioanal Nuclear Chem. 1988;125(1):19-28.

[22] Buxton GV, Stuart CR. Re-evaluation of the thiocyanate dosimeter for pulse radiolysis. Faraday Trans. 1995;91(2):279-281.

[23] Wardman P. Reduction potentials of one-electron couples involving free radicals in aqueous solution. J Phys Chem Ref Data. 1989;18(4):1637-1755.

[24] Trudinger PA. On the absorbancy of reduced methyl viologen. Anal Biochem. 1970;36(1):222-225.

[25] Scott SL, Chen WJ, Bakac A, et al. Spectroscopic parameters, electrode potentials, acid ionization constants, and electron exchange rates of the 2,2'-azinobis(3-ethylbenzothiazoline-6-sulfonate) radicals and ions. J Phys Chem. 1993;97(25):6710-6714.

[26] Wolfenden BS, Willson RL. Radical-cations as reference chromogens in kinetic studies of ono-electron transfer reactions: pulse radiolysis studies of 2,2'-azinobis-(3ethylbenzthiazoline-6-sulphonate). J Chem Soc Perkin Trans 2. 1982;(7):805-812.

[27] Veltwisch D, Asmus K-D. On the reaction of methyl and phenyl radicals with $p$-benzoquinone in aqueous solution. J Chem Soc Perkin Trans 2. 1982;(9): 1147-1152.

[28] Cermenati L, Pichat P, Guillard C, et al. Probing the $\mathrm{TiO}_{2}$ photocatalytic mechanisms in water purification by use of quinoline, photo-Fenton generated $\mathrm{OH}^{\bullet}$ radicals and superoxide dismutase. J Phys Chem B. 1997; 101(14):2650-2658.

[29] Nicolaescu AR, Wiest O, Kamat PV. Radical-induced oxidative transformation of quinoline. J Phys Chem A. 2003;107(3):427-433.

[30] Kovács $\mathrm{K}$, $\mathrm{He} \mathrm{S}$, Mile $\mathrm{V}$, et al. Ionizing radiation induced degradation of diuron in dilute aqueous solution. Chem Cent J. 2015;9:21.

[31] Kovács $\mathrm{K}, \mathrm{He} \mathrm{S}$, Míle $\mathrm{V}$, et al. Ionizing radiation induced degradation of monuron in dilute aqueous solution. Radiat Phys Chem. 2016;124:191-197.

[32] Simić $M$, Neta $P$, Hayon E. Pulse radiolytic investigation of aliphatic amines in aqueous solution. Int J Radiat Phys Chem. 1971;3(3):309-320.

[33] Szabó L, Mile V, Tóth T, et al. On the complex ${ }^{\bullet} \mathrm{OH} /{ }^{\bullet} \mathrm{O}^{-}$induced free radical chemistry of arylalkylamines with special emphasis on the contribution of the alkylamine side chain. Free Radic Res. 2017;51(2):124-140.

[34] Rózsa G, Szabó L, Schrantz K, et al. Mechanistic study on thiacloprid transformation: free radical reactions. J Photochem Photobiol Chem. 2017;343:17-25.

[35] Buxton GV, Greenstock CL, Helman WP, et al. Critical review of rate constants for reactions of hydrated electrons, hydrogen atoms and hydroxyl radicals ${ }^{\circ} \mathrm{OH} / \mathrm{O}^{-}$in Aqueous Solution. J Phys Chem Ref Data. 1988;17(2):513-886.

[36] Zhu D-Z, Sun D-M, Jiang Z-L, et al. Studies on the respective reactions of quinoline and isoquinoline with transient species by pulse radiolysis. Acta Phys Chim Sin. 2008;24:2321-2326.

[37] Aikawa M, Sumiyoshi T, Miura N, et al. Dynamic studies on electron transport across micellar phase. Intermicellar migration of hydrated electrons. BCSJ. 1982;55(8):2352-2355. 
[38] Ruscoe JE, Tingle MD, O'Neill PM, et al. Effect of disposition of mannich antimalarial agents on their pharmacology and toxicology. Antimicrob Agents Chemother. 1998;42(9):2410-2416.

[39] Mvula E, Schuchmann MN, von Sonntag C. Reactions of phenol-OH-adduct radicals. Phenoxyl radical formation by water elimination vs. oxidation by dioxygen. J Chem Soc Perkin Trans 2. 2001;(3):264-268.

[40] Homlok R, Takács E, Wojnárovits L. Degradation of organic molecules in advanced oxidation processes: relation between chemical structure and degradability. Chemosphere. 2013;91(3):383-389. 